\title{
Radiative lifetime and oscillator strength determinations in Sm III
}

\author{
E. Biémont ${ }^{1,2}$, H. P. Garnir ${ }^{1}$, U. Litzén ${ }^{3}$, K. Nielsen ${ }^{3}$, P. Quinet ${ }^{1,2}$, S. Svanberg ${ }^{4}$, G. M. Wahlgren ${ }^{3}$, and Z. G. Zhang ${ }^{4}$ \\ 1 Astrophysique et Spectroscopie, Université de Mons-Hainaut, 7000 Mons, Belgium \\ 2 IPNAS (Bât. B15), Université de Liège, Sart Tilman, 4000 Liège, Belgium \\ 3 Lund Observatory, Box 43, Lund University, 22100 Lund, Sweden \\ ${ }^{4}$ Department of Physics, Lund Institute of Technology, PO Box 118, 22100 Lund, Sweden
}

Received 25 October 2002 / Accepted 22 November 2002

\begin{abstract}
Radiative lifetimes of 6 levels belonging to the $4 \mathrm{f}^{5}\left({ }^{6} \mathrm{H}^{\circ},{ }^{6} \mathrm{~F}^{\circ}\right) 5 \mathrm{~d}$ configuration of Sm III have been measured for the first time using a time-resolved laser-induced fluorescence technique. Experimental data have been compared with semiempirical calculations. The agreement is excellent for 4 levels with ${ }^{6} \mathrm{~F}^{\circ}$ as a parent term. Larger discrepancies (53 and $\left.37 \%\right)$ are observed for 2 levels with ${ }^{6} \mathrm{H}^{\circ}$ and ${ }^{6} \mathrm{~F}^{\circ}$, respectively, as a parent term and are explainable by strong mixing and cancellation effects occurring in the line strength calculations which are responsible of "instabilities" occurring in the lifetimes considered as a function of $J$ value within the term. Branching ratios for the lines depopulating the levels of interest have been measured by Fourier transform spectroscopy. A first set of oscillator strengths has been deduced for this ion.
\end{abstract}

Key words. atomic processes - atomic data - stars: chemically peculiar

\section{Introduction}

Samarium $(Z=62)$, one of the lanthanides, has seven stable isotopes and isomers $(144,147,148,149,150,152$ and 154). They are present in the solar system in absolute proportions $3,15,11,14,7,27$ and $23 \%$, respectively. ${ }^{146} \mathrm{Sm}$ has a half life of $7 \times 10^{7}$ years and is used for radioactive dating. In the stars, ${ }^{144} \mathrm{Sm}$ is produced by the p process, ${ }^{148} \mathrm{Sm}$ and ${ }^{150} \mathrm{Sm}$ by the s process, ${ }^{154} \mathrm{Sm}$ by the $\mathrm{r}$ process while ${ }^{147} \mathrm{Sm},{ }^{149} \mathrm{Sm}$ and ${ }^{152} \mathrm{Sm}$ can be produced by both the $\mathrm{r}$ and s processes (Jaschek \& Jaschek 1995).

There is a need for transition probabilities of RE ions in stellar physics, particularly for $\mathrm{Sm}^{2+}$, in relation to the determination of the chemical composition of some stars, particularly for the study of chemically peculiar (CP) stars, which show large overabundances of lanthanides when compared to the solar system composition.

Singly-ionized samarium $\left(\mathrm{Sm}^{+}\right)$has been observed in many types of stars. In particular, the three transitions at 456.6, 471.9 and $673.1 \mathrm{~nm}$ appear in the spectral types F5 to M2 (see, e.g. Gopka \& Komarov 1990). Sm II lines have been found, frequently enhanced, in Ap stars of the $\mathrm{Cr}-\mathrm{Eu}-\mathrm{Sr}$ subgroup (Aikman et al. 1979), in Bp stars (Cowley \& Crosswhite 1978), in Am (Smith 1974), in Ba stars (Danziger 1965; Lambert 1985), in S-type stars (Bidelman 1953), in metal-weak G and K dwarfs (Gilroy et al. 1988) and in galactic halo stars

Send offprint requests to: E. Biémont,

e-mail: E.Biemont@ulg.ac.be

or P. Quinet, e-mail: quinet@umh.ac. be
(Sneden et al. 1996). The strength of the Sm II lines, in comparison with those of Nd II, has been discussed by Cowley (1976, 1984). Sm II has also been found to be present in the extreme peculiar star HD 101065 (Przybylski's star) with a confidence level $=95 \%$ (Cowley \& Mathys 1998; Cowley et al. 2000).

The spectrum of doubly ionized samarium (Sm III) belongs to the $\mathrm{Nd} \mathrm{I}$ isoelectronic sequence with $[\mathrm{Xe}] 4 \mathrm{f}^{6}{ }^{7} \mathrm{~F}_{0}$ as the ground state. Although extensive laboratory observations of the $\mathrm{Sm}^{2+}$ spectrum have been carried out by Dupont (1966, 1967), who listed about 15000 lines in the wavelength range $180.0-950.0 \mathrm{~nm}$, only 43 levels have been reported in the NIST compilation of lanthanide element energy levels (Martin et al. 1978). These level assignments allowed them to classify only about 100 lines in the region $193.5-403.3 \mathrm{~nm}$ as belonging to the $4 \mathrm{f}^{6}{ }^{7} \mathrm{~F}-4 \mathrm{f}^{5}\left({ }^{6} \mathrm{H}^{\circ},{ }^{6} \mathrm{~F}^{\circ},{ }^{6} \mathrm{P}^{\circ}\right) 5 \mathrm{~d}$ transition array. This indicates that our knowledge of this spectrum is still extremely fragmentary. The lowest $4 \mathrm{f}^{6}{ }^{5} \mathrm{D}$ level has been obtained from the $\mathrm{BaClF}$ : $\mathrm{Sm}^{2+}$ data of Kiss \& Weakliem (1965) with an uncertainty of several hundred $\mathrm{cm}^{-1}$.

Although some Sm III lines are suggested to be present in the line list prepared by Cowley \& Mathys (1998) and by Cowley et al. (2000), $\mathrm{Sm}^{2+}$ has been much less studied in stellar spectra than $\mathrm{Sm}^{+}$in view of the lack of atomic data which are needed for a quantitative abundance study. Sm III lines have been identified (Cowley \& Crosswhite 1978) in a Bp star of the Si subgroup (HD 192913). Aikman et al. (1979) also showed that Sm III was a highly confident identification in the RE maximum spectrum of the Ap star HR 465. Cowley (1976) and 
Table 1. Excitation schemes in Sm III.

\begin{tabular}{lrrcc}
\hline \hline $\begin{array}{l}\text { Measured } \\
\begin{array}{l}\text { level } \\
\left(\mathrm{cm}^{-1}\right)\end{array}\end{array}$ & $\begin{array}{r}\text { Origin } \\
\text { level } \\
\left(\mathrm{cm}^{-1}\right)\end{array}$ & $\begin{array}{r}\lambda_{\text {exc }} \\
(\mathrm{nm})\end{array}$ & $\begin{array}{c}\lambda_{\text {obs }} \\
(\mathrm{nm})\end{array}$ & $\begin{array}{c}\text { Nonlinear } \\
\text { scheme }^{\mathrm{b}}\end{array}$ \\
\hline 29763.82 & 293.45 & 339.26 & 345.3 & $2 v_{1}+S$ \\
35314.66 & 293.45 & 285.46 & 295.6 & $2 v_{2}$ \\
35928.00 & 813.55 & 284.70 & 297.1 & $2 v_{2}$ \\
36826.12 & 1492.66 & 282.94 & 296.7 & $2 v_{2}$ \\
36931.88 & 293.45 & 272.86 & 276.8 & $2 v_{1}+A S$ \\
37715.91 & 813.55 & 270.91 & 276.0 & $2 v_{1}+A S$
\end{tabular}

a From Martin et al. (1978).

b $v_{1}$ and $v_{2}$ designate the frequencies of the DCM and R6G dye lasers; $\mathrm{S}$ and AS mean Stokes and anti-Stokes components; $2 v$ indicates frequency-doubling.

Cowley \& Greenberg (1988) presented evidence for the presence of Sm III in the spectrum of the same star. Sm III transitions have also been identified in the spectrum of the CP star HR 465 (Bidelman et al. 1985).

For these reasons, we present in this paper the first lifetime measurements and oscillator strength determination in the Sm III spectrum. More precisely, lifetimes were obtained using time-resolved laser-induced fluorescence emitted from a laser-produced plasma. Configuration interaction calculations including some relativistic effects were also performed for comparison with the measurements.

This work is part of an extensive program of lifetime measurements in doubly-ionized lanthanides carried out at the Lund Laser Centre (LLC) in Sweden and of transition probability calculations at Liège and Mons universities. The results obtained so far concern the following ions: La III ( $\mathrm{Li} \&$ Jiang 1999), La III - Lu III (Biémont et al. 1999), Ce III (Li et al. 2000; Biémont et al. 2002a), Gd III (Zhang et al. 2001a; Biémont et al. 2002b), Tb III (Biémont et al. 2002c), Er III (Biémont et al. 2001a), Pr III (Palmeri et al. 2000; Biémont et al. 2001b), Tm III (Li et al. 2001), Yb III (Biémont et al. 2001c; Zhang et al. 2001b), Eu III (Zhang et al. 2000), Ho III (Zhang et al. 2002a; Biémont et al. 2001d), Dy III (Zhang et al. 2002b) and Nd III (Zhang et al. 2002c). More details are given in a database of astrophysical interest, D.R.E.A.M. at the address: http://www . umh . ac. be/ astro/dream. shtml.

\section{Measurements}

The six levels of Sm III, considered in the present experiment, belong to the configuration $4 \mathrm{f}^{5}\left({ }^{6} \mathrm{H}^{\circ},{ }^{6} \mathrm{~F}^{\circ}\right) 5 \mathrm{~d}$ and their lifetimes have been measured using a time-resolved laser-induced fluorescence technique developed at the Lund Laser Centre (LLC, Lund, Sweden). Free ions were obtained by laser ablation and excited from low lying metastable states belonging to the configuration $4 \mathrm{f}^{6}$. The experimental schemes followed for the measurements are summarized in Table 1.

In order to obtain the suitable excitation, 8 ns pulses emitted by a Nd:YAG laser (Continuum NY-82) were sent to a stimulated Brillouin scattering (SBS) compressor to shorten the
Table 2. Theoretical and experimental radiative lifetimes (in ns) for the $4 \mathrm{f}^{5} 5 \mathrm{~d}$ levels of Sm III. Only calculated lifetimes shorter than $1 \mu \mathrm{s}$ are given.

\begin{tabular}{|c|c|c|c|c|c|c|}
\hline Configuration & Term & $J$ & $E\left(\mathrm{~cm}^{-1}\right)$ & $H F R(A)^{\mathrm{a}}$ & $H F R(B)^{\mathrm{b}}$ & Experiment \\
\hline \multirow[t]{6}{*}{$4 f^{5}\left({ }^{6} H^{\circ}\right) 5 d$} & ${ }^{7} \mathrm{G}^{\circ}$ & 1 & 28634.34 & 102 & 222 & \\
\hline & & 2 & 29763.82 & 78 & 169 & $110 \pm 20$ \\
\hline & & 3 & 30608.25 & 67 & 147 & \\
\hline & & 4 & 31556.56 & 69 & 150 & \\
\hline & & 5 & 32341.80 & 74 & 161 & \\
\hline & & 6 & 33710.00 & 78 & 170 & \\
\hline \multirow[t]{6}{*}{$4 f^{5}\left({ }^{6} \mathrm{~F}^{\circ}\right) 5 \mathrm{~d}$} & ${ }^{7} \mathrm{~F}^{\circ}$ & 1 & 34846.60 & 21 & 45.1 & \\
\hline & & 2 & 35314.66 & 21 & 44.9 & $46 \pm 5$ \\
\hline & & 3 & 35928.00 & 21 & 44.3 & $52 \pm 5$ \\
\hline & & 4 & 36826.12 & 20 & 43.6 & $52 \pm 5$ \\
\hline & & 5 & 37738.44 & 20 & 42.2 & \\
\hline & & 6 & 38758.03 & 23 & 50.0 & \\
\hline \multirow{5}{*}{$4 f^{5}\left({ }^{6} F^{\circ}\right) 5 d$} & ${ }^{7} \mathrm{D}^{\circ}$ & 1 & 36347.54 & 35 & 75.6 & \\
\hline & & 2 & 36931.88 & 36 & 78.9 & $75 \pm 8$ \\
\hline & & 3 & 37715.91 & 45 & 99.5 & $72 \pm 7$ \\
\hline & & 4 & 38714.36 & 40 & 86.6 & \\
\hline & & 5 & 39666.78 & 34 & 73.9 & \\
\hline
\end{tabular}

HFR calculations with the configurations $4 f^{6}+4 f^{5} 6 p$ and $4 f^{5} 5 d+$ $4 \mathrm{f}^{5} 6 \mathrm{~s}$ included:

a $H F R(A)$ : No core-polarization effects included.

b $\operatorname{HFR}(B)$ : Core-polarization effects included and $4 \mathrm{f}-5 \mathrm{~d}$ dipole scaled down by a factor of 0.68 (see the text).

pulses down to about 1 ns. The laser was used to pump a dye laser (Continuum Nd-60), which operated with DCM or R6G dyes. Frequency-doubling of the dye laser emission in a KDP crystal, sometimes followed by stimulated Raman scattering in a hydrogen cell, was used to generate the excitation light.

$\mathrm{Sm}^{2+}$ ions were produced in a laser-induced plasma using $532 \mathrm{~nm}$ wavelength laser pulses emitted from another Nd:YAG laser (Continuum Surelite) with $10 \mathrm{~Hz}$ repetition rate and $10 \mathrm{~ns}$ duration. The pulse energy of the ablation laser usually was in the range of $2-5 \mathrm{~mJ}$. The two Nd:YAG lasers were triggered by a digital delay generator (Stanford Research Systems, Model 535) and the delay between the ablation and excitation pulses could be suitably adjusted in the experiments. When the ablation laser was focused perpendicularly onto the surface of a samarium foil rotating in a vacuum chamber, an expanding plasma was produced, composed of ions in different ionization stages. Free $\mathrm{Sm}^{2+}$ ions always move faster than both $\mathrm{Sm}^{+}$ions and $\mathrm{Sm}$ atoms. After a certain time, the $\mathrm{Sm}^{2+}$ ions, populated in the ground level and in different metastable states, came into the interaction zone, about $1 \mathrm{~cm}$ above the foil. The ions were excited selectively by the excitation laser crossing the plasma in a plane parallel to the foil. The fluorescence decay was imaged by two $\mathrm{CaF}_{2}$ lenses and concentrated onto the entrance slit of a vacuum monochromator. A Hamamatsu R3809U-58 photomultiplier was used for the detection. The time-resolved signal was averaged with a digital transient recorder (Tektronix model DSA 602) and the fluorescence decay curve was sent to a personal computer for lifetime determination. The details about the experimental set-up can be found elsewhere (Zhang et al. 2001a; 2002a,b,c). 
In order to be sure that the $\mathrm{Sm}^{2+}$ lines of interest were considered, the modification of the fluorescence signal as a function of the delay time was investigated. In the lifetime measurements of the level of $\mathrm{Sm}^{2+}$ at $36826.12 \mathrm{~cm}^{-1}$, the excitation laser light populated simultaneously both the level of $\mathrm{Sm}^{2+}$ and a level of $\mathrm{Sm}^{+}$. This was evidenced by changing the delay time, because there was still a fluorescence signal when the delay time was more than $2 \mu$ s (usually we only could see the signal with a shorter delay time i.e. in the range $1.6-1.8 \mathrm{~ms}$ ). The $\mathrm{Sm}^{2+}$ line at $282.93 \mathrm{~nm}$ was blended with the $\mathrm{Sm}^{+}$transition at $282.92 \mathrm{~nm}$. Consequently, in order to eliminate the influence of the $\mathrm{Sm}^{+}$line, the excitation wavelength was increased slightly so that only the $\mathrm{Sm}^{2+}$ ions were excited.

The possible flight-out-of-view effects were carefully avoided by enlarging the slit of the monochromator. As a further refinement, a magnetic field of about 120 Gauss was added in the plasma zone by a pair of Helmholtz coils in order to eliminate possible Zeeman quantum beat effects but also to weaken the background associated with the ablation laser and the plasma recombination processes. Although the use of a magnetic field was efficient for removing the background in some previously studied doubly-ionized lanthanides, it could, however, in certain cases not be taken away completely. When this situation occurred in the measurements, the final decay curve was always obtained after subtraction of the averaged signal, without the excitation laser light, from the recorded fluorescence decay curve.

The energies of the ablation pulses were changed when recording the different curves in the lifetime measurements for each level considered. Accordingly, this means that the curves were observed in different plasma conditions including modifications of temperature and concentration. No systematic trend was observed, which showed that collisions or trapping effects could be neglected in our experiments. Each decay curve was obtained by averaging fluorescence photons from more than 4000 pulses in order to obtain a sufficiently high signal-tonoise ratio. The lifetime evaluation was performed by fitting the fluorescence decay signal to an exponential function with adjustable parameters. For each level, the final lifetime was obtained by averaging the evaluated lifetimes of all the recorded curves. The six lifetimes measured are reported in Table 2 where the quoted uncertainties reflect not only the statistical errors, but were increased to include also possible small remaining systematic errors.

\section{Pseudo-relativistic calculations}

The doubly-ionized lanthanides have generally an electronic structure with an open $4 \mathrm{f}$ shell $\left(4 \mathrm{f}^{5}\right.$ in the case of Sm III) and, in addition, one or two outer excited electrons. Configurations, such as $4 \mathrm{f}^{N} n l$, particularly with $N=4-10$, generate large energy matrices and, in view of the computer limitations, it is possible to consider in the atomic structure calculations performed with the relativistic Hartree-Fock (HFR) code (Cowan 1981) only a very limited number of interacting configurations despite the fact that the simultaneous consideration, in the theoretical models, of both intravalence and core-valence interactions is expected to be crucial.
In Sm III, in view of the huge matrix dimensions involved in the calculations, we were only able to include explicitly in the HFR model adopted the experimentally known configurations, i.e. $4 f^{6}+4 f^{5} 6 p$ for the even parity and $4 f^{5} 5 d+4 f^{5} 6 s$ configurations for the odd parity. The adopted sets of configurations, i.e. $4 f^{6}, 4 f^{5} 6 p, 4 f^{5} 5 d$ and $4 f^{5} 6 s$ represent 293,1168 , 1878 and 396 possible energy levels, respectively, while only 43 levels have been reported in the NIST compilation (Martin et al. 1978). According to this compilation, very few energy levels have been determined experimentally in Sm III. Indeed, in the even parity, only the eight levels within the ${ }^{7} \mathrm{~F}$ multiplet of the $4 \mathrm{f}^{6}$ ground configuration have been established while, in the odd parity, 35 energy level values have been determined within the $4 f^{5} 5 d$ configuration. Additional levels have been reported in Dupont's thesis (Dupont 1966) but many of them, which have been omitted from the NIST compilation (Martin et al. 1978), are uncertain. The attempts to include some of these levels, particularly those characterized by the lowest energies, in the fitting procedures failed. Consequently, these levels were not further considered in the present work and, finally, we only retained the levels from the NIST compilation.

From a theoretical point of view, detailed comparisons between HFR calculations and accurate experimental radiative lifetimes in Er III (Biémont et al. 2001a) and Tm III (Li et al. 2001) have emphasized the fact that, in lanthanides, the $4 \mathrm{f}^{N}-$ $4 \mathrm{f}^{N-1} 5 \mathrm{~d}$ transitions deserve special attention in relation with the collapse of the $4 \mathrm{f}$ orbitals inside the xenon-like core. A possibility to solve the problem, originating from the fact that the analytical core-polarization and core-penetration corrections to the dipole operator (see e.g. Quinet et al. 1999) are no more valid, consists in applying an empirical scaling factor to the uncorrected $<4 \mathrm{f}|r| 5 \mathrm{~d}>$ radial matrix element. In the present work, this procedure was followed and the best scaling factor was found to be equal to 0.68 . Consequently, it was introduced in the present calculation.

The HFR method was combined with a least-squares optimization process minimizing the differences between the experimental energy levels and the Hamiltonian eigenvalues. All the experimental levels taken from the NIST compilation were fitted if we exclude the four levels of the $4 \mathrm{f}^{5}\left({ }^{6} \mathrm{P}^{\circ}\right) 5 \mathrm{~d}^{7} \mathrm{D}^{\circ}$ multiplet situated at $51160.80(J=1), 51432.29(J=2), 51940.36$ $(J=3)$ and $53149.58(J=4) \mathrm{cm}^{-1}$ which lie amid many unknown levels belonging to the $4 \mathrm{f}^{5} 5 \mathrm{~d}$ and $4 \mathrm{f}^{5} 6 \mathrm{~s}$ configurations. In fact, according to our calculations, in the region between 40000 and $55000 \mathrm{~cm}^{-1}$, there are several dozens of energy levels which are not known experimentally. In order to avoid any error in the optimization process and to focus on the $4 \mathrm{f}^{5}\left({ }^{6} \mathrm{H}^{\circ}\right) 5 \mathrm{~d}$ and $4 \mathrm{f}^{5}\left({ }^{6} \mathrm{~F}^{\circ}\right) 5 \mathrm{~d}$ subconfigurations for which some radiative lifetimes have been measured in the present work, we have preferred not to introduce the $4 \mathrm{f}^{5}\left({ }^{6} \mathrm{P}^{\circ}\right) 5 \mathrm{~d}$ levels in our semi-empirical approach. This avoids forcing the theoretical eigenvalues to converge to eventually false or erroneously assigned level values. The adopted parameters are reported in Table 3 while the comparison between experimental and HFR energy levels together with calculated Landé $g$-factors and the leading LS components for the $4 \mathrm{f}^{5} 5 \mathrm{~d}$ configuration are listed in Table 4. As expected, some levels appear strongly mixed and the level designations adopted from the NIST table sometimes 
Table 3. Numerical values adopted in this work for the radial parameters of the $4 f^{6}$ and $4 f^{5} 5 d$ configurations. The ratios between fitted and $a b$ initio values are also given in the table.

\begin{tabular}{llrl}
\hline \hline Config. & Parameter & $\begin{array}{r}\text { Value } \\
\left(\mathrm{cm}^{-1}\right)\end{array}$ & Ratio \\
\hline $4 \mathrm{f}^{6}$ & $\mathrm{E}_{\mathrm{av}}$ & 59064 & \\
& $\mathrm{~F}^{2}(4 \mathrm{f}, 4 \mathrm{f})$ & 85875 & $0.850^{\mathrm{a}}$ \\
& $\mathrm{F}^{4}(4 \mathrm{f}, 4 \mathrm{f})$ & 53545 & $0.850^{\mathrm{a}}$ \\
& $\mathrm{F}^{6}(4 \mathrm{f}, 4 \mathrm{f})$ & 38427 & $0.850^{\mathrm{a}}$ \\
& $\zeta_{4 \mathrm{f}}$ & 1063 & 0.937 \\
$4 \mathrm{f}^{5} 5 \mathrm{~d}$ & & & \\
& $\mathrm{E}_{\mathrm{av}}$ & 80644 & \\
& $\mathrm{~F}^{2}(4 \mathrm{f}, 4 \mathrm{f})$ & 77826 & 0.714 \\
& $\mathrm{~F}^{4}(4 \mathrm{f}, 4 \mathrm{f})$ & 69634 & $1.018^{\mathrm{b}}$ \\
& $\mathrm{F}^{6}(4 \mathrm{f}, 4 \mathrm{f})$ & 50088 & $1.018^{\mathrm{b}}$ \\
& $\zeta_{4 \mathrm{f}}$ & 1244 & 1.002 \\
& $\zeta_{5 \mathrm{~d}}$ & 741 & 0.794 \\
& $\mathrm{~F}^{2}(4 \mathrm{f}, 5 \mathrm{~d})$ & 24402 & 0.938 \\
& $\mathrm{~F}^{4}(4 \mathrm{f}, 5 \mathrm{~d})$ & 15637 & 1.240 \\
& $\mathrm{G}^{1}(4 \mathrm{f}, 5 \mathrm{~d})$ & 11291 & 0.929 \\
& $\mathrm{G}^{3}(4 \mathrm{f}, 5 \mathrm{~d})$ & 8083 & 0.830 \\
$\mathrm{G}^{5}(4 \mathrm{f}, 5 \mathrm{~d})$ & 9804 & 1.327 \\
\hline
\end{tabular}

a Parameter fixed to $85 \%$ of its ab initio value (see text).

b Ratio fixed (see text).

do not correspond, according to the present calculation, to the leading eigenvector component. Nevertheless, for coherence, we have kept everywhere the NIST notations.

According to Brewer (1971), the lowest configurations of Sm III could interact with $4 \mathrm{f}^{4} 5 \mathrm{~d}^{2}$ and $4 \mathrm{f}^{4} 5 \mathrm{~d} 6 \mathrm{~s}$ configurations whose mean energies are calculated to be 83000 and $106000 \mathrm{~cm}^{-1}$. These interactions, however, could not be taken into account in the present calculation in view of the computer limitations.

Experimental and theoretical radiative lifetimes obtained in the present study for the $4 \mathrm{f}^{5} 5 \mathrm{~d}$ levels are compared in Table 2 . The agreement is good for the $4 \mathrm{f}^{5}\left({ }^{6} \mathrm{~F}^{\circ}\right) 5 \mathrm{~d}$ levels but larger discrepancies (53 and 37\%) are observed for the $4 \mathrm{f}^{5}\left({ }^{6} \mathrm{H}^{\circ}\right) 5 \mathrm{~d}^{7} \mathrm{G}_{2}{ }^{\circ}$ and $4 \mathrm{f}^{5}\left({ }^{6} \mathrm{~F}^{\circ}\right) 5 \mathrm{~d}^{7} \mathrm{D}_{3}{ }^{\circ}$ levels. These fluctuations in the lifetime values, which are observed among the different $J$ values within the same term, are explainable by strong mixing occurring for the different $J$ values. In fact, according to the Table 4 , we observe that the composition of the $4 \mathrm{f}^{5}\left({ }^{6} \mathrm{H}^{\circ}\right) 5 \mathrm{~d}{ }^{7} \mathrm{G}_{2}{ }^{\circ}$ level is $43 \%\left({ }^{6} \mathrm{H}^{\circ}\right)^{7} \mathrm{G}^{\circ}+17 \%\left({ }^{6} \mathrm{H}^{\circ}\right)^{7} \mathrm{~F}^{\circ}+15 \%\left({ }^{6} \mathrm{H}^{\circ}\right)^{5} \mathrm{~F}^{\circ}$ according to the HFR calculation while, for the $4 \mathrm{f}^{5}\left({ }^{6} \mathrm{~F}^{\circ}\right) 5 \mathrm{~d}{ }^{7} \mathrm{D}_{3}{ }^{\circ}$ level, we find $72 \%\left({ }^{6} \mathrm{~F}^{\circ}\right)^{7} \mathrm{D}^{\circ}+7 \%\left({ }^{6} \mathrm{H}^{\circ}\right)^{5} \mathrm{H}^{\circ}+5 \%\left({ }^{6} \mathrm{~F}^{\circ}\right)^{5} \mathrm{H}^{\circ}$. It appears that the corresponding calculated lifetimes are very sensitive to these mixings and consequently, that the uncertainties affecting the theoretical lifetimes are probably larger.

\section{Branching fraction and transition probability determination}

The ratio between the transition probability for a transition and the sum of all transition probabilities for all possible transitions from a given upper level is defined as the branching fraction (BF). The intensity for a transition is proportional to the population and the statistical weight of the upper level and the transition probability, hence, branching fractions were in this analysis determined from integrated intensity measurements of all relevant Sm III lines found in the experimental wavelength region, supplemented by theoretical calculations for transitions outside the experimental domain. The transition probability is then calculated by dividing the determined BF by the radiative lifetime for the upper level.

Spectra of samarium between 22000 and $50000 \mathrm{~cm}^{-1}$ were recorded in Lund using a Chelsea Instrument VUV FT500 Fourier transform spectrometer (FTS) with a hollow cathode light source. The spectral region was divided into two recordings: all transitions originating from the $4 \mathrm{f}^{5}\left({ }^{6} \mathrm{H}^{\circ}\right) 5 \mathrm{~d}{ }^{7} \mathrm{G}^{\circ}$ and $4 \mathrm{f}^{5}\left({ }^{6} \mathrm{~F}^{\circ}\right) 5 \mathrm{~d}{ }^{7} \mathrm{~F}^{\circ}$ levels were included in one recording and the transitions from the $4 \mathrm{f}^{5}\left({ }^{6} \mathrm{~F}^{\circ}\right) 5 \mathrm{~d}^{7} \mathrm{D}^{\circ}$ level in the other. Observed intensity measurements were corrected for the response function of the detector and optical components in the instrument. The carrier gas for both spectral regions was argon, chosen for its usefulness in the intensity calibration. The well known branching fractions for decays from a large number of levels in Ar II (Whaling et al. 1993) were used for creating an instrumental response curve. This is useful below $30000 \mathrm{~cm}^{-1}$ and above $42000 \mathrm{~cm}^{-1}$, where the number of Ar II lines is sufficient, while in the intermediate spectral region the number of strong Ar II lines is smaller. For the spectral region between $30000-42000 \mathrm{~cm}^{-1}$ recordings were obtained with an identical instrumental setup, but with neon as the carrier gas. Branching fractions of Ne II have been published (Griesmann et al. 1997), and, by including these additional spectral lines, the accuracy of the instrumental response function was improved.

To derive BFs for an upper level all possible branches must be taken into account. The Sm III transitions to the ground state, $4 \mathrm{f}^{67} \mathrm{~F}$, are the only observable transitions in the recorded spectral region. A number of LS forbidden transitions to quintet and triplet states are possible, but not observable since they are weak and most of them are located outside our analysed wavelength region. The contribution from those transitions are, however, estimated by the Hartree-Fock calculations previously described and included in the calculation of the BFs but do not in any case give a significant contribution.

The uncertainty in the BF due to missing branches is for the measured transitions negligible compared to other errors in the process. The uncertainties presented in Table 5 are calculated with the method suggested by Sikström et al. (2002), and include the uncertainties in the intensity measurement and calibration.

In Table 5, we present the oscillator strengths of the transitions depopulating the ${ }^{7} \mathrm{D}^{\circ},{ }^{7} \mathrm{~F}^{\circ}$ and ${ }^{7} \mathrm{G}^{\circ}$ levels for which the lifetimes are reported in Table 2 . We include in Table 5 the upper and lower levels of the transitions, the air wavelengths (in $\mathrm{nm}$ ) measured by Dupont (1967), the relative intensities of the lines measured on the FTS spectra, the branching fractions with their uncertainties (in \%) and the weighted oscillator strengths in the logarithmic scale $(\log g f)$. Three sets of data are provided: the HFR results combined with the experimental BFs, the experimental results and, in the last column, the pure theoretical results (HFR calculation with core-polarization effects 
Table 4. Experimental and calculated energies, Landé $g$-factors and leading compositions for selected levels in the $4 \mathrm{f}^{5} 5 \mathrm{~d}$ configuration of Sm III.

\begin{tabular}{|c|c|c|c|c|c|c|}
\hline Term $^{\mathrm{a}}$ & $J$ & $\begin{array}{l}E_{\exp }^{\mathrm{a}} \\
\left(\mathrm{cm}^{-1}\right)\end{array}$ & $\begin{array}{c}E_{\mathrm{calc}}^{\mathrm{b}} \\
\left(\mathrm{cm}^{-1}\right)\end{array}$ & $\begin{array}{r}\Delta E^{\mathrm{b}} \\
\left(\mathrm{cm}^{-1}\right)\end{array}$ & $g_{\text {calc }}^{\mathrm{d}}$ & Leading components ${ }^{\mathrm{d}}$ \\
\hline $4 f^{5}\left({ }^{6} \mathrm{H}^{\circ}\right) 5 \mathrm{~d}^{7} \mathrm{H}^{\circ}$ & $\begin{array}{l}2 \\
3 \\
4 \\
5 \\
6 \\
7 \\
8\end{array}$ & $\begin{array}{l}26283.55 \\
27361.55\end{array}$ & $\begin{array}{l}26394 \\
27280 \\
28268 \\
29369 \\
30565 \\
31839 \\
33168\end{array}$ & $\begin{array}{r}-110 \\
82\end{array}$ & $\begin{array}{l}0.044 \\
0.595 \\
0.944 \\
1.123 \\
1.228 \\
1.296 \\
1.345\end{array}$ & $\begin{array}{l}67 \%\left({ }^{6} \mathrm{H}^{\circ}\right)^{7} \mathrm{H}^{\circ}+23 \%\left({ }^{6} \mathrm{~F}^{\circ}\right)^{7} \mathrm{H}^{\circ}+5 \%\left({ }^{6} \mathrm{H}^{\circ}\right)^{5} \mathrm{G}^{\circ} \\
43 \%\left({ }^{6} \mathrm{H}^{\circ}\right)^{7} \mathrm{H}^{\circ}+33 \%\left({ }^{6} \mathrm{H}^{\circ}\right)^{7} \mathrm{I}^{\circ}+17 \%\left({ }^{6} \mathrm{~F}^{\circ}\right)^{7} \mathrm{H}^{\circ} \\
41 \%\left({ }^{6} \mathrm{H}^{\circ}\right)^{7} \mathrm{H}^{\circ}+36 \%\left({ }^{6} \mathrm{H}^{\circ}\right)^{7} \mathrm{I}^{\circ}+18 \%\left({ }^{6} \mathrm{~F}^{\circ}\right)^{7} \mathrm{H}^{\circ} \\
40 \%\left({ }^{6} \mathrm{H}^{\circ}\right)^{7} \mathrm{H}^{\circ}+38 \%\left({ }^{6} \mathrm{H}^{\circ}\right)^{7} \mathrm{I}^{\circ}+19 \%\left({ }^{6} \mathrm{~F}^{\circ}\right)^{7} \mathrm{H}^{\circ} \\
39 \%\left({ }^{6} \mathrm{H}^{\circ}\right)^{7} \mathrm{H}^{\circ}+38 \%\left({ }^{6} \mathrm{H}^{\circ}\right)^{7} \mathrm{I}^{\circ}+20 \%\left({ }^{6} \mathrm{~F}^{\circ}\right)^{7} \mathrm{H}^{\circ} \\
40 \%\left({ }^{6} \mathrm{H}^{\circ}\right)^{7} \mathrm{H}^{\circ}+36 \%\left({ }^{6} \mathrm{H}^{\circ}\right)^{7} \mathrm{I}^{\circ}+21 \%\left({ }^{6} \mathrm{~F}^{\circ}\right)^{7} \mathrm{H}^{\circ} \\
46 \%\left({ }^{6} \mathrm{H}^{\circ}\right)^{7} \mathrm{H}^{\circ}+27 \%\left({ }^{6} \mathrm{H}^{\circ}\right)^{7} \mathrm{I}^{\circ}+22 \%\left({ }^{6} \mathrm{~F}^{\circ}\right)^{7} \mathrm{H}^{\circ}\end{array}$ \\
\hline $4 f^{5}\left({ }^{6} H^{\circ}\right) 5 d^{7} F^{\circ}$ & $\begin{array}{l}0 \\
1 \\
2 \\
3 \\
4 \\
5 \\
6\end{array}$ & $\begin{array}{l}27885.89 \\
28228.81 \\
29121.36 \\
30198.89 \\
31376.56 \\
32868.01\end{array}$ & $\begin{array}{l}28079 \\
27848 \\
28225 \\
28980 \\
30105 \\
31547 \\
33146\end{array}$ & $\begin{array}{r}38 \\
4 \\
141 \\
94 \\
-170 \\
-278\end{array}$ & $\begin{array}{l}0.763 \\
1.280 \\
1.399 \\
1.451 \\
1.478 \\
1.489\end{array}$ & $\begin{array}{l}84 \%\left({ }^{6} \mathrm{H}^{\circ}\right)^{7} \mathrm{~F}^{\circ}+11 \%\left({ }^{6} \mathrm{~F}^{\circ}\right)^{7} \mathrm{~F}^{\circ}+2 \%\left({ }^{4} \mathrm{G}^{\circ}\right)^{5} \mathrm{D}^{\circ} \\
43 \%\left({ }^{6} \mathrm{H}^{\circ}\right)^{7} \mathrm{~F}^{\circ}+34 \%\left({ }^{6} \mathrm{H}^{\circ}\right)^{5} \mathrm{~F}^{\circ}+7 \%\left({ }^{6} \mathrm{~F}^{\circ}\right)^{5} \mathrm{~F}^{\circ} \\
50 \%\left({ }^{6} \mathrm{H}^{\circ}\right)^{7} \mathrm{~F}^{\circ}+27 \%\left({ }^{6} \mathrm{H}^{\circ}\right)^{5} \mathrm{~F}^{\circ}+7 \%\left({ }^{6} \mathrm{~F}^{\circ}\right)^{7} \mathrm{~F}^{\circ} \\
55 \%\left({ }^{6} \mathrm{H}^{\circ}\right)^{7} \mathrm{~F}^{\circ}+21 \%\left({ }^{6} \mathrm{H}^{\circ}\right)^{5} \mathrm{~F}^{\circ}+9 \%\left({ }^{6} \mathrm{~F}^{\circ}\right)^{7} \mathrm{~F}^{\circ} \\
61 \%\left({ }^{6} \mathrm{H}^{\circ}\right)^{7} \mathrm{~F}^{\circ}+15 \%\left({ }^{6} \mathrm{H}^{\circ}\right){ }^{5} \mathrm{~F}^{\circ}+11 \%\left({ }^{6} \mathrm{~F}^{\circ}\right){ }^{7} \mathrm{~F}^{\circ} \\
70 \%\left({ }^{6} \mathrm{H}^{\circ}\right)^{7} \mathrm{~F}^{\circ}+13 \%\left({ }^{6} \mathrm{~F}^{\circ}\right)^{7} \mathrm{~F}^{\circ}+7 \%\left({ }^{6} \mathrm{H}^{\circ}\right){ }^{5} \mathrm{~F}^{\circ} \\
75 \%\left({ }^{6} \mathrm{H}^{\circ}\right)^{7} \mathrm{~F}^{\circ}+16 \%\left({ }^{6} \mathrm{~F}^{\circ}\right)^{7} \mathrm{~F}^{\circ}+4 \%\left({ }^{6} \mathrm{H}^{\circ}\right)^{7} \mathrm{G}^{\circ}\end{array}$ \\
\hline $4 f^{5}\left({ }^{6} H^{\circ}\right) 5 d^{7} G^{\circ}$ & $\begin{array}{l}1 \\
2 \\
3 \\
4 \\
5 \\
6 \\
7\end{array}$ & $\begin{array}{l}28634.34 \\
29763.82 \\
30608.25 \\
31556.56 \\
32341.80 \\
33710.00\end{array}$ & $\begin{array}{l}28767 \\
29589 \\
30487 \\
31447 \\
32498 \\
33648 \\
34873\end{array}$ & $\begin{array}{r}-133 \\
175 \\
121 \\
110 \\
-156 \\
62\end{array}$ & $\begin{array}{l}0.461 \\
0.995 \\
1.192 \\
1.300 \\
1.362 \\
1.400 \\
1.421\end{array}$ & $\begin{array}{l}35 \%\left({ }^{6} \mathrm{H}^{\circ}\right)^{7} \mathrm{~F}^{\circ}+25 \%\left({ }^{6} \mathrm{H}^{\circ}\right)^{7} \mathrm{G}^{\circ}+22 \%\left({ }^{6} \mathrm{H}^{\circ}\right)^{5} \mathrm{~F}^{\circ} \\
43 \%\left({ }^{6} \mathrm{H}^{\circ}\right)^{7} \mathrm{G}^{\circ}+17 \%\left({ }^{6} \mathrm{H}^{\circ}\right)^{7} \mathrm{~F}^{\circ}+15 \%\left({ }^{6} \mathrm{H}^{\circ}\right)^{5} \mathrm{~F}^{\circ} \\
50 \%\left({ }^{6} \mathrm{H}^{\circ}\right)^{7} \mathrm{G}^{\circ}+30 \%\left({ }^{6} \mathrm{~F}^{\circ}\right)^{7} \mathrm{G}^{\circ}+7 \%\left({ }^{6} \mathrm{H}^{\circ}\right)^{5} \mathrm{~F}^{\circ} \\
46 \%\left({ }^{6} \mathrm{H}^{\circ}\right)^{7} \mathrm{G}^{\circ}+45 \%\left({ }^{6} \mathrm{~F}^{\circ}\right)^{7} \mathrm{G}^{\circ}+3 \%\left({ }^{6} \mathrm{H}^{\circ}\right)^{5} \mathrm{~F}^{\circ} \\
56 \%\left({ }^{6} \mathrm{~F}^{\circ}\right)^{7} \mathrm{G}^{\circ}+38 \%\left({ }^{\circ} \mathrm{H}^{\circ}\right)^{7} \mathrm{G}^{\circ}+1 \%\left({ }^{6} \mathrm{H}^{\circ}\right)^{5} \mathrm{~F}^{\circ} \\
60 \%\left({ }^{6} \mathrm{~F}^{\circ}\right)^{7} \mathrm{G}^{\circ}+33 \%\left({ }^{6} \mathrm{H}^{\circ}\right)^{7} \mathrm{G}^{\circ}+1 \%\left({ }^{6} \mathrm{~F}^{\circ}\right)^{7} \mathrm{~F}^{\circ} \\
60 \%\left({ }^{6} \mathrm{~F}^{\circ}\right)^{7} \mathrm{G}^{\circ}+35 \%\left({ }^{6} \mathrm{H}^{\circ}\right)^{7} \mathrm{G}^{\circ}+1 \%\left({ }^{6} \mathrm{~F}^{\circ}\right)^{5} \mathrm{H}^{\circ}\end{array}$ \\
\hline $4 f^{5}\left({ }^{6} F^{\circ}\right) 5 d^{7} G^{\circ}$ & $\begin{array}{l}1 \\
2 \\
3 \\
4 \\
5 \\
6 \\
7\end{array}$ & $\begin{array}{l}30048.48 \\
30948.50 \\
31657.02 \\
32598.82 \\
33771.89\end{array}$ & $\begin{array}{l}30025 \\
31268 \\
31837 \\
32618 \\
33646 \\
34867 \\
36243\end{array}$ & $\begin{array}{r}23 \\
-319 \\
-180 \\
-19 \\
126\end{array}$ & $\begin{array}{r}-0.217 \\
0.838 \\
1.173 \\
1.285 \\
1.353 \\
1.393 \\
1.420\end{array}$ & $\begin{array}{l}34 \%\left({ }^{6} \mathrm{H}^{\circ}\right)^{7} \mathrm{G}^{\circ}+31 \%\left({ }^{6} \mathrm{~F}^{\circ}\right)^{7} \mathrm{G}^{\circ}+19 \%\left({ }^{6} \mathrm{H}^{\circ}\right)^{5} \mathrm{~F}^{\circ} \\
53 \%\left({ }^{6} \mathrm{~F}^{\circ}\right)^{7} \mathrm{G}^{\circ}+38 \%\left({ }^{6} \mathrm{H}^{\circ}\right)^{7} \mathrm{G}^{\circ}+2 \%\left({ }^{6} \mathrm{~F}^{\circ}\right)^{5} \mathrm{~F}^{\circ} \\
43 \%\left({ }^{6} \mathrm{H}^{\circ}\right)^{7} \mathrm{G}^{\circ}+35 \%\left({ }^{6} \mathrm{~F}^{\circ}\right)^{7} \mathrm{G}^{\circ}+6 \%\left({ }^{6} \mathrm{H}^{\circ}\right)^{7} \mathrm{~F}^{\circ} \\
45 \%\left({ }^{6} \mathrm{H}^{\circ}\right)^{7} \mathrm{G}^{\circ}+43 \%\left({ }^{6} \mathrm{~F}^{\circ}\right)^{7} \mathrm{G}^{\circ}+3 \%\left({ }^{6} \mathrm{~F}^{\circ}\right)^{7} \mathrm{H}^{\circ} \\
50 \%\left({ }^{6} \mathrm{H}^{\circ}\right)^{7} \mathrm{G}^{\circ}+35 \%\left({ }^{6} \mathrm{~F}^{\circ}\right)^{7} \mathrm{G}^{\circ}+4 \%\left({ }^{6} \mathrm{~F}^{\circ}\right)^{7} \mathrm{H}^{\circ} \\
53 \%\left({ }^{6} \mathrm{H}^{\circ}\right)^{7} \mathrm{G}^{\circ}+34 \%\left({ }^{6} \mathrm{~F}^{\circ}\right)^{7} \mathrm{G}^{\circ}+4 \%\left({ }^{6} \mathrm{~F}^{\circ}\right)^{7} \mathrm{H}^{\circ} \\
57 \%\left({ }^{6} \mathrm{H}^{\circ}\right)^{7} \mathrm{G}^{\circ}+36 \%\left({ }^{6} \mathrm{~F}^{\circ}\right)^{7} \mathrm{G}^{\circ}+3 \%\left({ }^{6} \mathrm{~F}^{\circ}\right)^{7} \mathrm{H}^{\circ}\end{array}$ \\
\hline $4 f^{5}\left({ }^{6} F^{\circ}\right) 5 d^{7} F^{\circ}$ & $\begin{array}{l}0 \\
1 \\
2 \\
3 \\
4 \\
5 \\
6\end{array}$ & $\begin{array}{l}34846.60 \\
35314.66 \\
35928.00 \\
36826.12 \\
37738.44 \\
38758.03\end{array}$ & $\begin{array}{l}34677 \\
34913 \\
35374 \\
36022 \\
36832 \\
37787 \\
38968\end{array}$ & $\begin{array}{r}-66 \\
-59 \\
-94 \\
-6 \\
-49 \\
-210\end{array}$ & $\begin{array}{l}1.498 \\
1.503 \\
1.501 \\
1.498 \\
1.494 \\
1.456\end{array}$ & $\begin{array}{l}79 \%\left({ }^{6} \mathrm{~F}^{\circ}\right)^{7} \mathrm{~F}^{\circ}+12 \%\left(\left({ }^{6} \mathrm{H}^{\circ}\right)^{7} \mathrm{~F}^{\circ}+3 \%\left({ }^{6} \mathrm{P}^{\circ}\right)^{7} \mathrm{~F}^{\circ}\right. \\
79 \%\left({ }^{6} \mathrm{~F}^{\circ}\right)^{7} \mathrm{~F}^{\circ}+13 \%\left({ }^{6} \mathrm{H}^{\circ}\right)^{7} \mathrm{~F}^{\circ}+3 \%\left({ }^{6} \mathrm{P}^{\circ}\right)^{7} \mathrm{~F}^{\circ} \\
78 \%\left({ }^{6} \mathrm{~F}^{\circ}\right)^{7} \mathrm{~F}^{\circ}+13 \%\left({ }^{6} \mathrm{H}^{\circ}\right)^{7} \mathrm{~F}^{\circ}+3 \%\left({ }^{6} \mathrm{P}^{\circ}\right)^{7} \mathrm{~F}^{\circ} \\
77 \%\left({ }^{6} \mathrm{~F}^{\circ}\right)^{7} \mathrm{~F}^{\circ}+14 \%\left(\left({ }^{6} \mathrm{H}^{\circ}\right)^{7} \mathrm{~F}^{\circ}+3 \%\left({ }^{6} \mathrm{P}^{\circ}\right)^{7} \mathrm{~F}^{\circ}\right. \\
74 \%\left({ }^{6} \mathrm{~F}^{\circ}\right)^{7} \mathrm{~F}^{\circ}+16 \%\left({ }^{6} \mathrm{H}^{\circ}\right)^{7} \mathrm{~F}^{\circ}+3 \%\left({ }^{6} \mathrm{~F}^{\circ}\right)^{7} \mathrm{D}^{\circ} \\
72 \%\left({ }^{6} \mathrm{~F}^{\circ}\right)^{7} \mathrm{~F}^{\circ}+17 \%\left(\left({ }^{6} \mathrm{H}^{\circ}\right)^{7} \mathrm{~F}^{\circ}+3 \%\left({ }^{6} \mathrm{~F}^{\circ}\right)^{7} \mathrm{D}^{\circ}\right. \\
58 \%\left({ }^{6} \mathrm{~F}^{\circ}\right)^{7} \mathrm{~F}^{\circ}+16 \%\left({ }^{6} \mathrm{H}^{\circ}\right)^{7} \mathrm{~F}^{\circ}+13 \%\left({ }^{6} \mathrm{H}^{\circ}\right)^{5} \mathrm{G}^{\circ}\end{array}$ \\
\hline $4 f^{5}\left({ }^{6} F^{\circ}\right) 5 d^{7} D^{\circ}$ & $\begin{array}{l}2 \\
3 \\
4 \\
5\end{array}$ & $\begin{array}{l}36347.54 \\
36931.88 \\
37715.91 \\
38714.36 \\
39666.78\end{array}$ & $\begin{array}{l}36305 \\
36807 \\
37578 \\
38551 \\
39615\end{array}$ & $\begin{array}{r}42 \\
125 \\
138 \\
163 \\
52\end{array}$ & $\begin{array}{l}2.946 \\
1.969 \\
1.537 \\
1.633 \\
1.586\end{array}$ & $\begin{array}{l}92 \%\left({ }^{6} \mathrm{~F}^{\circ}\right)^{7} \mathrm{D}^{\circ}+3 \%\left({ }^{6} \mathrm{~F}^{\circ}\right)^{5} \mathrm{P}^{\circ}+1 \%\left({ }^{4} \mathrm{~F}^{\circ}\right)^{5} \mathrm{P}^{\circ} \\
91 \%\left({ }^{6} \mathrm{~F}^{\circ}\right)^{7} \mathrm{D}^{\circ}+2 \%\left({ }^{6} \mathrm{~F}^{\circ}\right)^{5} \mathrm{D}^{\circ}+2 \%\left({ }^{6} \mathrm{~F}^{\circ}\right)^{5} \mathrm{P}^{\circ} \\
72 \%\left({ }^{6} \mathrm{~F}^{\circ}\right)^{7} \mathrm{D}^{\circ}+7 \%\left({ }^{6} \mathrm{H}^{\circ}\right)^{5} \mathrm{H}^{\circ}+5 \%\left({ }^{6} \mathrm{~F}^{\circ}\right)^{5} \mathrm{H}^{\circ} \\
80 \%\left(\left({ }^{6} \mathrm{~F}^{\circ}\right)^{7} \mathrm{D}^{\circ}+9 \%\left({ }^{6} \mathrm{~F}^{\circ}\right)^{7} \mathrm{P}^{\circ}+3 \%\left({ }^{6} \mathrm{~F}^{\circ}\right)^{7} \mathrm{~F}^{\circ}\right. \\
92 \%\left({ }^{6} \mathrm{~F}^{\circ}\right)^{7} \mathrm{D}^{\circ}+3 \%\left({ }^{6} \mathrm{~F}^{\circ}\right)^{7} \mathrm{~F}^{\circ}+1 \%\left({ }^{6} \mathrm{H}^{\circ}\right)^{5} \mathrm{~F}^{\circ}\end{array}$ \\
\hline
\end{tabular}

a From the NIST compilation (Martin et al. 1978).

b Present work (HFR calculation).

c $\Delta E=E_{\text {exp }}-E_{\text {calc }}$.

d Only the three main components are quoted.

included). It is seen that these sets of data are generally in good agreement, notable discrepancies appearing only for a limited number of transitions. This clearly shows the difficulty (both on the theoretical and on the experimental sides) to obtain very accurate radiative data in a complex case like Sm III, particularly for transitions of the type $4 \mathrm{f}-5 \mathrm{~d}$.
It is expected that the new set of atomic data obtained in the present work will help the astrophysicists for the line identification and abundance determination work based on the UV high resolution spectra which are now becoming currently available (see, e.g., the HST spectra) particularly for the CP stars. Table 5 in particular contains the radiative data for the lines considered 
Table 5. Wavelengths, relative intensities, branching fractions and oscillator strengths $(\log g f)$ of intense $4 \mathrm{f}^{6}-4 \mathrm{f}^{5} 5 \mathrm{~d}$ transitions of $\mathrm{Sm}$ III depopulating the levels for which the lifetimes have been measured in the present work or the other levels within the same multiplets. The transitions quoted are not affected by cancellation effects $(C F>0.005)$. For details, see the text.

\begin{tabular}{|c|c|c|c|c|c|c|c|c|}
\hline Lower level & Upper level & $\lambda(\mathrm{nm})^{\mathrm{a}}$ & $\begin{array}{l}\text { Rel. intens. } \\
\quad \text { (corr.) }\end{array}$ & $B F$ & $\begin{array}{l}\text { Uncertainty } \\
(\% \text { in } B F)\end{array}$ & $H F R+B F$ & $\begin{array}{c}\log g f \\
E X P .\end{array}$ & $H F R+C P$ \\
\hline${ }^{7} \mathrm{~F}_{1}$ & $\left({ }^{6} \mathrm{~F}^{\circ}\right)^{7} \mathrm{~F}_{0}^{\circ}$ & $290.8309^{d}$ & & & & & & -1.55 \\
\hline${ }^{7} \mathrm{~F}_{0}$ & $\left({ }^{6} \mathrm{~F}^{\circ}\right)^{7} \mathrm{~F}_{1}^{\circ}$ & 286.8881 & & & & & & -1.56 \\
\hline${ }^{7} \mathrm{~F}_{1}$ & & 289.3246 & & & & & & -2.54 \\
\hline${ }^{7} \mathrm{~F}_{2}$ & & 293.7459 & & & & & & -1.27 \\
\hline${ }^{7} \mathrm{~F}_{1}$ & $\left({ }^{6} \mathrm{~F}^{\circ}\right)^{7} \mathrm{~F}_{2}^{\circ}$ & 285.4572 & 172 & 0.244 & 7 & -1.48 & -1.49 & -1.30 \\
\hline${ }^{7} \mathrm{~F}_{2}$ & & 289.7611 & 79 & 0.112 & 9 & -1.80 & -1.81 & -1.89 \\
\hline${ }^{7} \mathrm{~F}_{3}$ & & 295.5793 & 452 & 0.643 & 3 & -1.03 & -1.04 & -1.11 \\
\hline${ }^{7} \mathrm{~F}_{2}$ & $\left({ }^{6} \mathrm{~F}^{\circ}\right)^{7} \mathrm{~F}_{3}^{\circ}$ & 284.6994 & 177 & 0.236 & 6 & -1.34 & -1.41 & -1.17 \\
\hline${ }^{7} \mathrm{~F}_{3}$ & & 290.3143 & 206 & 0.275 & 6 & -1.26 & -1.33 & -1.45 \\
\hline${ }^{7} \mathrm{~F}_{4}$ & & 297.0889 & 367 & 0.489 & 4 & -0.99 & -1.06 & -1.01 \\
\hline${ }^{7} \mathrm{~F}_{3}$ & $\left({ }^{6} \mathrm{~F}^{\circ}\right)^{7} \mathrm{~F}_{4}^{\circ}$ & 282.9347 & 169 & 0.176 & 7 & -1.36 & -1.44 & -1.10 \\
\hline${ }^{7} \mathrm{~F}_{4}$ & & 289.3652 & 385 & 0.402 & 4 & -0.98 & -1.06 & -1.09 \\
\hline${ }^{7} \mathrm{~F}_{5}$ & & 296.6969 & 404 & 0.422 & 4 & -0.94 & -1.02 & -1.01 \\
\hline${ }^{7} \mathrm{~F}_{4}$ & $\left({ }^{6} \mathrm{~F}^{\circ}\right)^{7} \mathrm{~F}_{5}^{\circ}$ & 281.9204 & 149 & 0.138 & 7 & -1.37 & & -1.10 \\
\hline${ }^{7} \mathrm{~F}_{5}$ & & 288.8747 & 547 & 0.507 & 4 & -0.78 & & -0.78 \\
\hline${ }^{7} \mathrm{~F}_{6}$ & & 296.5484 & 383 & 0.355 & 5 & -0.91 & & -1.10 \\
\hline${ }^{7} \mathrm{~F}_{5}$ & $\left({ }^{6} \mathrm{~F}^{\circ}\right)^{7} \mathrm{~F}_{6}^{\circ}$ & 280.6071 & 75 & 0.080 & 10 & -1.61 & & -1.41 \\
\hline${ }^{7} \mathrm{~F}_{6}$ & & 287.8423 & 854 & 0.918 & 1 & -0.53 & & -0.56 \\
\hline${ }^{7} \mathrm{~F}_{0}$ & $\left({ }^{6} \mathrm{~F}^{\circ}\right)^{7} \mathrm{D}_{1}^{\circ}$ & 275.0402 & & & & & & -1.92 \\
\hline${ }^{7} \mathrm{~F}_{1}$ & & 277.2785 & & & & & & -1.65 \\
\hline${ }^{7} \mathrm{~F}_{2}$ & & 281.3384 & & & & & & -1.95 \\
\hline${ }^{7} \mathrm{~F}_{1}$ & $\left({ }^{6} \mathrm{~F}^{\circ}\right)^{7} \mathrm{D}_{2}^{\circ}$ & 272.8568 & 22255 & 0.190 & 7 & -1.87 & -1.85 & -1.83 \\
\hline${ }^{7} \mathrm{~F}_{2}$ & & 276.7859 & 58154 & 0.498 & 4 & -1.44 & -1.42 & -1.45 \\
\hline${ }^{7} \mathrm{~F}_{3}$ & & 282.0901 & 36315 & 0.311 & 6 & -1.63 & -1.61 & -1.64 \\
\hline${ }^{7} \mathrm{~F}_{2}$ & $\left({ }^{6} \mathrm{~F}^{\circ}\right)^{7} \mathrm{D}_{3}^{\circ}$ & 270.9054 & 32137 & 0.226 & 6 & -1.76 & -1.62 & -1.90 \\
\hline${ }^{7} \mathrm{~F}_{3}$ & & 275.9842 & 60580 & 0.426 & 4 & -1.47 & -1.32 & -1.41 \\
\hline${ }^{7} \mathrm{~F}_{4}$ & & 282.0995 & 48871 & 0.344 & 5 & -1.54 & -1.40 & -1.52 \\
\hline${ }^{7} \mathrm{~F}_{3}$ & $\left({ }^{6} \mathrm{~F}^{\circ}\right)^{7} \mathrm{D}_{4}^{\circ}$ & 268.5809 & 13636 & 0.103 & 7 & -1.93 & & -1.89 \\
\hline${ }^{7} \mathrm{~F}_{4}$ & & 274.3687 & 54661 & 0.414 & 5 & -1.32 & & -1.27 \\
\hline${ }^{7} \mathrm{~F}_{5}$ & & 280.9517 & 63487 & 0.481 & 5 & -1.23 & & -1.27 \\
\hline${ }^{7} \mathrm{~F}_{4}$ & $\left({ }^{6} \mathrm{~F}^{\circ}\right)^{7} \mathrm{D}_{5}^{\circ}$ & 267.3796 & 9907 & 0.055 & 7 & -2.06 & & -2.06 \\
\hline${ }^{7} \mathrm{~F}_{5}$ & & 273.6271 & 59781 & 0.333 & 6 & -1.25 & & -1.25 \\
\hline${ }^{7} \mathrm{~F}_{6}$ & & 280.5024 & 109787 & 0.611 & 4 & -0.97 & & -0.97 \\
\hline${ }^{7} \mathrm{~F}_{0}$ & $\left({ }^{6} \mathrm{H}^{\circ}\right)^{7} \mathrm{G}_{1}^{\circ}$ & 349.1303 & & & & & & -2.96 \\
\hline${ }^{7} \mathrm{~F}_{1}$ & & 352.7452 & & & & & & -1.92 \\
\hline${ }^{7} \mathrm{~F}_{2}$ & & $359.3409^{c}$ & & & & & & -1.93 \\
\hline${ }^{7} F_{1}$ & $\left({ }^{6} \mathrm{H}^{\circ}\right)^{7} \mathrm{G}_{2}^{\circ}$ & 339.2261 & 809 & 0.066 & 6 & -2.47 & -2.28 & -1.99 \\
\hline${ }^{7} \mathrm{~F}_{2}$ & & 345.3209 & 7242 & 0.594 & 3 & -1.50 & -1.32 & -1.52 \\
\hline${ }^{7} \mathrm{~F}_{3}$ & & 353.6165 & 4050 & 0.332 & 4 & -1.73 & -1.55 & -1.90 \\
\hline${ }^{7} \mathrm{~F}_{2}$ & $\left({ }^{6} \mathrm{H}^{\circ}\right)^{7} \mathrm{G}_{3}^{\circ}$ & 335.5337 & 3551 & 0.254 & 4 & -1.69 & & -1.51 \\
\hline${ }^{7} \mathrm{~F}_{3}$ & & 343.3599 & 7741 & 0.554 & 3 & -1.33 & & -1.36 \\
\hline${ }^{7} \mathrm{~F}_{4}$ & & 352.8773 & 2653 & 0.190 & 5 & -1.77 & & -2.04 \\
\hline${ }^{7} \mathrm{~F}_{3}$ & $\left({ }^{6} \mathrm{H}^{\circ}\right)^{7} \mathrm{G}_{4}^{\circ}$ & $332.5287^{b}$ & 7057 & 0.307 & 5 & -1.51 & & -1.26 \\
\hline${ }^{7} \mathrm{~F}_{4}$ & & 341.4475 & 7185 & 0.313 & 4 & -1.48 & & -1.37 \\
\hline${ }^{7} \mathrm{~F}_{5}$ & & 351.7026 & 8697 & 0.379 & 3 & -1.37 & & -2.32 \\
\hline${ }^{7} \mathrm{~F}_{4}$ & $\left({ }^{6} \mathrm{H}^{\circ}\right)^{7} \mathrm{G}_{5}^{\circ}$ & $332.5287^{b}$ & & & & & & -1.10 \\
\hline${ }^{7} \mathrm{~F}_{5}$ & & 342.2462 & & & & & & -1.49 \\
\hline${ }^{7} \mathrm{~F}_{6}$ & & $353.0711^{\mathrm{c}}$ & & & & & & -2.81 \\
\hline${ }^{7} \mathrm{~F}_{5}$ & $\left({ }^{6} \mathrm{H}^{\circ}\right)^{7} \mathrm{G}_{6}^{\circ}$ & 326.9329 & 10013 & 0.933 & 1 & -0.94 & & -0.96 \\
\hline${ }^{7} \mathrm{~F}_{6}$ & $\left({ }^{6} \mathrm{H}^{\circ}\right)^{7} \mathrm{G}_{6}^{\circ}$ & $336.7963^{c}$ & 711 & 0.066 & 7 & -2.06 & & -1.85 \\
\hline${ }^{7} \mathrm{~F}_{6}$ & $\left({ }^{6} \mathrm{H}^{\circ}\right)^{7} \mathrm{G}_{7}^{\circ}$ & $324.2036^{\mathrm{d}}$ & & & & & & -0.82 \\
\hline
\end{tabular}

a Experimental wavelengths from Dupont (1966).

b Blend.

c Wavelength calculated using the NIST energy levels (Martin et al. 1978).

d HFR calculated wavelength. 
by Cowley and Greenberg (1988) in their study of CP stars from IUE spectra which showed consistent evidence for the presence of Sm III lines.

Acknowledgements. This work was financially supported by the Swedish Research Council and by the EU-IHP Access to Research Infrastructures Programme (contract HPRI-CT-1999-00041). Financial support from the Belgian FNRS is acknowledged by two of us (E.B. and P.Q).

\section{References}

Aikman, G. C. L., Cowley, C. R., \& Crosswhite, H. M. 1979, ApJ, 232,812

Bidelman, W. P. 1953, ApJ, 117, 377

Bidelman, W. P., Cowley, C. R., \& Iler, A. L. 1985, Wavelength Identification in the Magnetic CP star HR 465 (Publ. Obs. Michigan, USA) Vol. XII, $\mathrm{n}^{\circ} 3$

Biémont, E., Li, Z. S., Palmeri, P., \& Quinet, P. 1999, J. Phys. B: At. Mol. Opt. Phys., 32, 3409

Biémont, E., Garnir, H. P., Bastin, T., et al. 2001a, MNRAS, 321, 481

Biémont, E., Garnir, H. P., Palmeri, P., et al. 2001b, Phys. Rev. A, 64, 022503

Biémont, E., Garnir, H. P., Li, Z. S., et al. 2001c, J. Phys. B: At. Mol. Opt. Phys., 34, 1869

Biémont, E., Palmeri, P., Quinet, P., et al. 2001d, MNRAS, 328, 1085

Biémont, E., Quinet, P., \& Ryabchikova, T. A. 2002a, MNRAS, in press

Biémont, E., Kohnen, G., \& Quinet, P. 2002b, A\&A, 393, 717

Biémont, E., Garnir, H. P., Quinet, P., Svanberg, S., \& Zhang, Z. G. 2002c, Phys. Rev. A, 65, 052502

Brewer, L. 1971, JOSA 61, 1666

Cowan, R. D. 1981, The Theory of Atomic Structure and Spectra (University of California Press, Berkeley, CA, USA)

Cowley, C. R. 1976, ApJS, 32, 631

Cowley, C. R. 1984, Phys. Scr., T8, 28

Cowley, C. R., \& Crosswhite, H. M. 1978, PASP, 90, 108

Cowley, C. R., \& Greenberg, M. 1988, MNRAS, 232, 763

Cowley, C. R., \& Mathys, G. 1998, A\&A, 339, 165

Cowley, C. R., Ryabchikova, T. R., Kupla, F., et al. 2000, MNRAS, 317,299
Danziger, L. 1965, MNRAS, 131, 51

Dupont, A. 1966, The Spectrum of Doubly Ionized Samarium, Ph.D. Thesis, University of Baltimore, USA

Dupont, A. 1967, JOSA, 57, 867

Gilroy, K. K., Sneden, C., Pilachowski, C., \& Cowan, J. J. 1988, ApJ, 327, 298

Gopka, V. F., \& Komarov, N. S. 1990, Sov. Astron., 34, 610

Griesmann, U., Musielok, J., \& Wiese, W. L. 1997, JOSA B, 14, 9

Jaschek, C., \& Jaschek, M. 1995, The Behavior of Chemical Elements in Stars (Cambridge University Press, London)

Kiss, Z., \& Weakliem, H. A. 1965, Phys. Rev. Lett., 15, 457

Lambert, D. L. 1985, in Cool Stars with Excesses of Heavy Elements, ed. M. Jaschek, \& P. C. Keenan (Reidel, Amsterdam)

Li, Z. S., \& Jiang, Z. K. 1999, Phys. Scr., 60, 414

Li, Z. S., Lundberg, H., Wahlgren, G. M., \& Sikström, C. M. 2000, Phys. Rev. A, 62, 032505

Li, Z. S., Zhang, Z. G., Lokhnygin, V., et al. 2001, J. Phys. B: At. Mol. Opt. Phys., 34, 1349

Martin, W. C., Zalubas, R., \& Hagan, L. 1978, Atomic Energy Levels, The Rare-Earth Elements, Nat. Bur. Stand. Ref. Data Ser., 60 (Washington D.C. , USA)

Palmeri, P., Quinet, P., Frémat, Y., Wyart, J. F., \& Biémont, E. 2000, ApJS, 129, 367

Quinet, P., Palmeri, P., Biémont, E., et al. 1999, MNRAS, 307, 934

Sikström, C. M., Nilsson, H., Litzén, U., Blom, A., \& Lundberg, H. 2002, J. Quant. Spectrosc. Radiat. Transfer, 74, 355

Smith, M. A. 1974, ApJ, 189, 101

Sneden, C., McWilliam, A., Preston, G. W., et al. 1996, ApJ, 467, 819

Whaling, W., Carle, M. T., \& Pitt, M. L. 1993, J. Quant. Spectrosc. Radiat. Transfer, 50, 7

Zhang, Z. G., Li, Z. S., Lundberg, H., et al. 2000, J. Phys. B: At. Mol. Opt. Phys., 33, 521

Zhang, Z. G., Li, Z. S., Svanberg, S., et al. 2001b, Eur. Phys. J. D, 15, 301

Zhang, Z. G., Persson, A., Li, Z. S., Svanberg, S., \& Jiang, Z. K. 2001a, Eur. Phys. J. D, 13, 301

Zhang, Z. G., Somesfalean, G., Svanberg, S., et al. 2002a, A\&A, 384, 364

Zhang, Z. G., Svanberg, S., Palmeri, P., Quinet, P., \& Biémont, E. 2002b, MNRAS, in press

Zhang, Z. G., Svanberg, S., Palmeri, P., Quinet, P., \& Biémont, E. 2002c, A\&A, 385, 724 